\title{
Determinasi Pembiayaan Murabahah Berbasis Analisis Resiko Pada Bank Umum Syariah di Indonesia
}

\author{
Laely Aghe Africa ${ }^{1}$ \\ ${ }^{1}$ Sekolah Tinggi Ilmu Ekomomi Perbanas, Surabaya, Indonesia
}

\section{INFO ARTIKEL \\ JEL Classification :}

G32, G21

\section{Keywords :}

Murabahah, risk analysis, sharia bank

\begin{abstract}
Majority of people in Indonesia prefer Murabahah financing to other types of loans in Indonesia Sharia Banks. Murabahah financing must also be influenced by a number of factors in the banking industry. This research aimed to analyze whether the following factors such us credit risk, liquidity risk and operational risk can influence Murabahah Financing.Credit risk is proxied by CKPN (Allowance For Impairment Losses Of Credits), NPF (Non Performing Financing), Risk Concentration of Funds Distribution to Core Debtors. Liquidity risk is proxy by FDR (Financing to Depoit Ratio) and profit sharing financing to total financing, Operational risk is proxied by BOPO (Operating Expense To Operating Revenue). This study uses secondary data from the Indonesia Stock Exchange for the period 2009-2018. Data analysis technique used in this study is multiple linear regression analysis techniques using SPSS 23. The result of the study are that credit risk and liquidity risk affect to Murabahah Financing. Beside that, it has implication for Islamic banking companies can minimize the risks that exist in company so that Murabahah financing continues to demand the customer.
\end{abstract}

\begin{abstract}
ABSTRAK
Mayoritas masyarakat di Indonesia lebih memilih jenis peminjaman Murabahah daripada jenis pinjaman lainnya pada Bank Syariah di Indonesia. Pembiayaan murabahah juga pastinya dipengaruhi oleh beberapa faktor pada industri perbankan. Penelitian ini bertujuan untuk menganalisa beberapa faktor yang dapat mempengaruhi pembiayaan murabahah berdasarkan beberapa rasio risiko antara lain risiko kredit, risiko likuiditas dan risiko operasional, dimana untuk risiko kredit diproksikan dengan rasio Cadangan Kerugian Penurunan Nilai (CKPN), Non Performing Financing (NPF), Konsentrasi Risiko Penyaluran Dana Kepada Debitur Inti. Risiko Likuiditas diproksikan dengan rasio Financing to Depoit Ratio (FDR) dan pembiayaan bagi hasil terhadap total pembiayaan, Sedangkan risiko Operasional diproksikan oleh rasio Biaya Operasional Pendapatan Operasional (BOPO). Penelitian ini menggunakan data sekunder dari Bursa Efek Indonesia (BEI) periode 2009-2018. Teknik analisis data yang digunakan pada penelitian ini ialah teknik analisis regresi linear berganda dengan menggunakan SPSS 23. Hasil dari penelitian adalah bahwa risiko kredit dan risiko likuiditas berpengaruh terhadap pembiayaan murabahah. Disamping itu Implikasi untuk perusahaan perbankan syariah dapat lebih
\end{abstract}


meminimalisasikan risiko-risiko yang ada diperusahaan agar pembiayaan Murabahah sesuai dengan permintaan nasabah.

\section{Pendahuluan}

Pemenuhan fasilitas kredit dari industri perbankan tetap dibutuhkan oleh pelaku bisnis, baik dari sisi UMKM maupun pelaku bisnis Non UMKM, maka kredibilitas perusahaan yang baik tetap dibutuhkan karena akan memberikan efek positif terhadap pelaku bisnis, disisi lain industri perbankan juga membutuhkan banyaknya nasabah baik sebagai nasabah DPK maupun sebagai nasabah peminjam yang kita sebut dengan Debitur. Rakyat Indonesia dengan penduduk mayoritas beragama islam, membutuhkan industri perbankan yang mempunyai dasar secara Islam, sejak tahun 2009 Bank Indonesia memberikan perijinan pertama kali untuk membuka Bank Umum Syariah dan adanya kepastian dibidang hukum dan diversifikasi produk perbankan syariah yang diatur dalam Undang-Undang No. 21 Tahun 2008 tentang Perbankan Syariah, UndangUndang No.19 tahun 2008 tentang Surat Berharga Syariah Negara serta UndangUndang No.42 tahun 2009 tentang Amandemen ketiga Undang-Undang No. 8 Thaun 2983 tebtang PPN Barang dn jasa.

Bank merupakan suatu lembaga keuangan yang mempunyai asset keuangan sebagai kekayaannya serta bermotifkan profit dan juga sosial (Malayu S.P.Hasibuan 2004:2). Perkembangan perbankan Syariah dari sisi penyaluran belum stagnan karena prosentase kenaikan maupun penurunan belum bisa dipastikan dari tahun sebelumnya, penyaluran kredit tertinggi terjadi ditahun 2017 kurang lebih sekitar Rp. 3 Triliun atau tumbuh sekitar $46,9 \%$, dibandingkan tahun 2016 yang hanya mencapai 16,41\%, namun di tahun 2018 hanya $10,75 \%$, dari jumleh penyaluran kredit yang tersebar, pembiayaan Murabahah mempunyai nilai yang lebih tinggi dibandingkan dengan pembiayaan lainnya. Fenomena yang terjadi di tahun 2018 adalah tingkat suku bunga yang melambung dan melemahnya Rupiah terhadap Dollar membuat para pelaku bisnis enggan untuk mengajukan fasilitas kredit karena adanya ketakutan jika dikemudin hari berimbas pada pembiayaan terutama pada pembiayaan di perbankan syariah. Di semester awal 2019 ini pembiayaan di perbankan syariah semakin membaik diprediksi diangka $19 \%$.

Murabahah adalah akad jual beli barang dagangan dengan harga jual sebesar biaya perolehan ditambah dengan keuntungan yang disepakati dan penjual harus mengungkapkan biaya perolehan barang dagangan tersebut kepada pembeli (Yaya,Rizal 2014:168). Untuk jenis pembiayaan Murabahah ini cenderung lebih diminati oleh nasabah baik nasabah UMKM maupun Non UMKM, karena sistem pembayarannya yang lebih fleksibel dibanding dengan pembiayaan lainnya, dalam hal ini fleksibel dalam pembayarannya karena bisa dilakukan dengan mencicil ataupun dibayar secara tunai dan bahkan dapat dibayar dikemudian hari dengan sekali bayar. Pembiayaan Murabahah ini tentu saja sedikit banyak dipengaruhi oleh beberapa faktor, baik faktor internal dan eksternal. Salah satu faktor internal adalah beberapa indikator berbasis analisis risiko.

Terkait dengan analisis risiko, beberapa risiko yang digunakan dalam penelitian ini adalah risiko kredit, risiko likuiditas dan risiko operasional. Beberapa risiko yang digunakan dalam penelitian ini mempunyai pengaruh masing-masing dan hasilnya pun dari beberapa penelitian terdahulu juga beragam dan terdapat gap.

Perbedaaan hasil penelitian terdahulu dapat menimbulkan gap, penelitian yang dilakukan oleh Ali Herni dkk (2018) menyatakan bahwa Non Performing Financing (NPF) dan Beban Operasional Pendapatan Operasional (BOPO) tidak berpengaruh terhadap pembiayaan Murabahajh. Menurut Huseini, Uus Ahmad (2016) menyatakan bahwa FDR berpengaruh positif dan NPF tidak berpengaruh terhadap pembiayaan syariah. Amira, Siti Nor Bt Mohamad, etc (2014) bahwa risiko kredit berpengaruh terhadap pembiayaan Syariah. Sedangkan menurut Wardiantikan, Lifstin dkk (2016) bahwa Dana Pihak Ketiga (DPK) dan Non Perfoming Finance (NPF) berpengaruh terhadap pembiayaan Syariah, dan Capital Adequacy ratio (CAR). Adapun rumusan 
masalah dari penelitian ini adalah : apakah Risiko Kredit, risiko likuiditas dan risiko operasional berpengaruh terhadap Pembiayaan Murabahah di Bank Umum Syariah di Indonesia. Rumusan masalah dalam penelitian adalah Untuk mengetahui apakah Risiko Kredit, risiko likuiditas dan risiko operasional berpengaruh terhadap Pembiayaan Murabahah di Bank Umum Syariah di Indonesia.

Berdasarkan uraian tersebut diatas, baik dari sisi perkembangan penelitian-penelitian dan teori yang ada, maka penelitian ini berjudul "Determinasi Pembiayaan Murabahah Berbasis Analisis RIsiko Pada Bank Umum Syariah di Indonesia”.

\section{Telaah Teori dan Pengembangan Hipotesis}

Murabahah adalah akad jual beli barang dagangan dengan harga jual sebesar biaya perolehan ditambah dengan keuntungan yang disepakati dan penjual harus mengungkapkan biaya perolehan barang dagangan tersebut kepada pembeli (Rizal Yahya, 2014:168). Definisi lain dari Murabahah adalah menjual suatu barang dengan menegaskan harga belinya kepada pembeli, dan pembeli membayarnya dengan harga yang lebih tinggi sebagai laba (Salman, Kautsar Riza, 2017:220). Sedangkan dasar pembiayaan Murabahah ada pada :

\section{Al Qur'an}

“...Allah telah menghalalkan jual beli dan mengharamkan riba..." (AlBaqarah:275)

\section{Al Hadist}

Dari Suaib ar-Rumi r.a bahwa Rasulullah SAW berkata, "Tiga hal yang di dalamnya terdapat keberkahan: jual beli secara tangguh, muqaradhah (mudharabah), dan mencampur gandum dengan tepung untuk keperluan rumah, bukan untuk dijual" (HR Ibnu Majjab.)

Risiko usaha merupakan potensi kerugian yang akan terjadi akibat dari kegagalan kegiatan usaha bisnis bank. Secara umum yang termasuk risiko usaha antara lain : risiko kredit, risiko pasar, risiko likuiditas, risiko operasional, risiko hukum, risiko strategi, risiko kepatuhan dan reputasi. Namun dari beberapa resiko usaha bank yang bisa dihitung secara kuantitatif antara lain risiko kredit, risiko pasar, risiko likuiditas dan risiko operasional, dalam penelitian ini risiko yang digunakan antara lain risiko kredit, risiko likuiditas dan risiko operasional.

Risiko kredit terjadi jika ada kegagalan dari nasabah yang telah mendapatkan fasilitas kredit dari bank dalam menyelesaikan pembayaran atau bisa dikatakan sebagai wanprestasi dari nasabah. Beberapa rasio untuk mengukur risiko kredit yaitu : CKPN (Cadangan Kerugian Penurunan Nilai), NPF (Non Performing Financing), Aset Produktif Bermasalah dan Konsentrasi Resiko Penyaluran Dana Kepada Debitur Inti (KRDI).

Risiko Likuiditas terjadi jika pihak bank tidak mampu dalam menyediakan sumber dana yang liquid untuk memenuhi semua kewajibannya serta ketidaksanggupan bank dalam memenuhi permintaan kredit yang diajukan. Beberapa rasio untuk mengukur risiko likuiditas yaitu: FDR (Financing to Deposit Ratio) , Pembiayaan Bagi Hasil Terhadap Total Pembiayaa, IPR (Investing Policy Ratio) RDI (Rasio Deposan Inti) dan RAPB (Rasio antar Bank Pasiva).

Risiko Operasional terjadi ketika tidak berfungsinya proses internal dalam bank, adanya kesalahan manusia, terjadinya kegagalan sistem, dan kejadian eksternal yang mempengaruhi operasional Bank. Beberapa rasio untuk mengukur risiko operasional yaitu : BOPO (Biaya Operasional Pendapatan Operasional) dan FBIR (Fee Based Income Ratio).

\section{Risiko Kredit}

Risiko kredit akan diproksikan dengan beberapa rasio, diantaranya :

\section{CKPN (Cadangan Kerugian Penurunan Nilai)}

CKPN adalah rasio yang mengukur porsi ckpn terhadap total kredit yang diberikan. CKPN kredit merupakan gabungan nilai cadangan dari beberapa kredit yang tergolong kolektibilitas 3 atau kurang lancar, kolektibilitas 4 atau diragukan dan kolektibiltas 5 atau macet. Formula yang digunakan untuk menghitung CKPN adalah : 


$$
\boldsymbol{C K P N}=\frac{\text { CKPN Kredit }}{\text { Total Kredit }} \times 100 \%
$$

\section{Non Performing Financing (NPF)}

Non perfoming Loan adalah rasio yang mengukur porsi kredit bermasalah dibandingkan total kredit yang diberikan. Kredit bermasalah merupakan gabungan nilai dari beberapa kredit yang tergolong kolektibilitas 3 atau kurang lancer, kolektibilitas 4 atau diragukan dan kolektibiltas 5 atau macet. Formula yang digunakan untuk menghitung NPL adalah :

$$
\boldsymbol{N P F}=\frac{\text { Kredit Bermasalah }}{\text { Total Kredit }} \times 100 \%
$$

\section{Konsentrasi Resiko Penyaluran Dana Kepada Debitur Inti (KRDI)}

Rasio ini untuk mengukur tingkat risiko debitir inti akibat konsentrasi penyluran dana kepada debitur inti. Data debitur inti mengacu pada ketentuan laporan berkala bank Umum Syariah. Formula untuk menghitung adalah sebagai berikut :

$$
\boldsymbol{K R \boldsymbol { I } I = \frac { \text { Pembiayaan Kepada Debitur Inti } } { \text { Ttal Pembiayaan } }}
$$

\section{Risiko Likuiditas}

Risiko Likuiditas diproksikan dengan beberapa rasio, diantaranya :

\section{Financing to Deposit Ratio (FDR)}

Financing to Deposit Ratio digunakan untuk menilai sejauh mana bank mampu menyalurkan kredit dari total dana pihak ketiga. Formula yang digunakan untuk menghitung LDR adalah :

$$
\boldsymbol{F D R}=\frac{\text { Total Kredit }}{\text { Total DPK }} \times 100 \%
$$

* DPK adalah dana pihak ketiga yang meliputi giro, tabungan, deposito dan sertifikat deposito. *

\section{Pembiayaan Bagi Hasil Terhadap Total Pembiayaan}

Pembiayaan Bagi hasil adalah seluruh pembiayaan dengan akad bagi hasil yang menggunakan metode profit and loss sharing maupun Revenue Sharing. Total pembiayaan hanya mencakup nilai dari pembiayaan kepada pihak ketiga bukan bank.

$\begin{aligned} & \text { Pembiayaan Bagi Hasil } \\ & \text { Terhadap Total Pembiayaan }\end{aligned}=\frac{\text { Pembiayaan Bagi Hasil }}{\text { Total Pembiayaan }} \times 100 \%$

\section{Risiko Operasional}

Risiko Operasional diproksikan dengan beberapa rasio, diantaranya :

\section{BOPO (Biaya Operasional Pendapatan Operasional)}

Biaya Operasional Pendapatan Operasional untuk mengukur tingkat efisiensi bank dalam meminimalkan biaya operaional untuk menghasilkan pendapatan operasional. Formula yang digunakan untuk menghitung BOPO adalah :

$$
\text { ВОРО }=\frac{\text { Biaya Beban Operasional }}{\begin{array}{c}
\text { Pendapatan Operasional } \\
\times 100 \%
\end{array}}
$$

Risiko Kredit mempengaruhi Pembiayaan Murabahah pada Bank Umum Syariah di Indonesia

Unsur dari risiko kridit diproksikan dengan beberapa rasio, salah satunya adalah CKPN (Cadangan Kerugian Penuruna Nilai), yaitu rasio yang digunakan untuk mengukur besarnya porsi CKPN terhadap total kredit yang diberikan. CKPN atas kredit merupakan gabungan nilai cadangan dari beberapa kredit yang tergolong kolektibilitas 3 atau kurang lancar, kolektibilitas 4 atau diragukan dan kolektibiltas 5 atau macet. Semakin tinggi nilai CKPN mengindikasikan bahwa risiko kredit perbankan semakin tinggi dan berdampak pada tingkat kesehatan bank dan secara tidak langsung pemenuhan akan penyaluran pembiayaan juga akan terganggu, oleh karena itu semakin tinggi nilai Cadangan Kerugian Penurunan Nilai (CKPN) maka semakin rendah Pembiayaan Murabahah atau dengan kata lain bahwa CKPN berpengaruh negatif terhadap Pembiayaan Murabahah.

Rasio lainnya yang mewakili risiko kredit adalah Non Performing Financing (NPF) digunakan untuk mengukur besarnya porsi kredit bermasalah dibandingkan total kredit yang diberikan. Kredit bermasalah merupakan gabungan nilai dari beberapa kredit yang tergolong kolektibilitas 3 atau kurang lancar, 
kolektibilitas 4 atau diragukan dan kolektibiltas 5 atau macet. Semakin tingginya porsi kredit yang bermasalah mengindikasikan bahwa perusahaan belum mampu mengelola nasabahnya dengan baik sehingga banyak sekali nasabah yang masuk dalam kolektibilitas 3, 4 bahkan 5, dengan demikian maka stabilitas keuangan perusahaan perbankan akan terganggu dan berdampak pada pembiayaan Murabahah, semakin tinggi NPF maka akan semakin menurun Pembiayaan Murabahah atau dengan kata lain bahwa NPF berpengaruh negatif terhadap Pembiayaan Murabahah. Teori tersebut didukung oleh penelitian yang dilakukan oleh wardiantika, Lifstin dkk (2016). Sedangkan rasio lainnya yang digunakan adalah Konsentrasi Resiko Penyaluran Dana Kepada Debitur Inti (KRDI), rasio ini untuk mengukur tingkat risiko debitir inti akibat konsentrasi penyluran dana kepada debitur inti, dan rasio ini belum pernah digunakan dalam penelitian-penelitian sebelumnya.

Berdasarkan uraian diatas, maka hipotesis yang dikembangkan adalah :

$\mathrm{H}_{1 \mathrm{a}}$ : Cadangan Kerugian Penurunan Nilai (CKPN) berpengaruh terhadap pembiayaan Murabahah.

$\mathrm{H}_{2 \mathrm{a}}$ : Non Performing Financing (NPF) berpengaruh terhadap pembiayaan Murabahah.

$\mathrm{H}_{3 \mathrm{a}}$ : Penyaluran Dana Kepada Debitur Inti (KRDI) berpengaruh terhadap pembiayaan Murabahah.

\section{Risiko Likuiditas mempengaruhi Pembiayaan Murabahah pada Bank Umum Syariah di Indonesia Bank Umum Syariah di Indonesia}

Unsur dari risiko likuiditas diproksikan dengan beberapa rasio, salah satunya adalah Financing to Deposit Ratio digunakan untuk menilai sejauh mana bank mampu menyalurkan kredit dari total dana pihak ketiga. Tingginya FDR mengindikasian bahwa total dana pihak ketiga mampu untuk mengcover jumlah pembiayaan yang disallurkan, nilai FDR maka semakin tinggi pula Pembiayaan Murabahah yang disalurkan atau dengan kata lain bahwa FDR berpengaruh positf terhadap Pembiayaan
Murabahah.. Teori tersebut didukung oleh penelitian yang dilakukan oleh Huseini, Uus Ahmad (2016). Rasio yang mewakili risiko likuiditas lainnya adalah Pembiayaan Bagi Hasil Terhadap Total Pembiayaan. Pembiayaan Bagi hasil adalah seluruh pembiayaan dengan akad bagi hasil yang menggunakan metode profit and loss sharing maupun Revenue Sharing. dan rasio ini belum pernah digunakan dalam penelitian-penelitian sebelumnya.

Berdasarkan uraian diatas, maka hipotesis yang dikembangkan adalah :

\section{$\mathrm{H}_{1 \mathrm{~b}}$ : Financing to Deposit Ratio (FDR) berpengaruh terhadap pembiayaan Murabahah. \\ $\mathrm{H}_{2 b}$ : Pembiayaan Bagi Hasil Terhadap Total Pembiayaan berpengaruh terhadap pembiayaan Murabahah.}

Risiko Operasional mempengaruhi Pembiayaan Murabahah pada Bank Umum Syariah di Indonesia Bank Umum Syariah di Indonesia

Unsur dari risiko operasional diproksikan dengan beberapa rasio, salah satunya adalah Beban Operasional Pendapatan Operasional untuk mengukur tingkat efisiensi bank dalam meminimalkan biaya operaional untuk menghasilkan pendapatan operasional. Semakin tinggi BOPO maka semakin rendah tingkat efisiensi perusahaan perbankan karena melambangnya beban-beban operasional yang dimiliki dan berpengaruh terhadap kmungkinan bahwa perusahaan susah mendapatkan dana tambahan yang dapat digunakan untuk memenuhi permintaan kredit nasabah. Oleh karena itu semakin tinggi Beban Operasional Pendapatan Operasional (BOPO) maka semakin rendah Pembiayaan Syariah atau dengan kata lain bahwa BOPO berpengaruh negatif terhadap Pembiayaan Murabahah.

Berdasarkan uraian diatas, maka hipotesis yang dikembangkan adalah :

$\mathrm{H}_{\mathrm{c}}$ : Beban Operasional Pendapatan Operasional (BOPO) berpengaruh terhadap Nilai Perusahaan.

\section{Metode Penelitian}

Penelitian kuantitatif dengan menggunakan data sekunder digunakan dalam 
penelitian ini, penelitian jenis kuantitatif ini mempunyai karakter-istik yaitu menjabarkan dalam bentuk gambaran deskripsi trend atau menjelaskan hubungan antar variabel, memberikan peran penting literature da-lam mengembangkan pertanyaan peneliti, justifikasi pertanyaan penelitian, adanya tujuan penelitian dan hipotesis,menganalisis trend dan menggunakan analisisi statistic dan interpreatasi hasil dengan membandingkan dengan hasil penelitian sebelumnya (Ghozali, 2016:9). Se-dangkan data sekunder adalah informasi yang dikumpulkan oleh orang lain bukan oleh peneliti dalam melaksanakan penelitian, beberapa sumber data sekunder antara lain, buku, jurnal, publikasi pemerintah tentang indikator ekonomi, data sen-sus, abstrak statistic, media, dan laporan tahunan perusahaan (Ghozali, 2016:94).

Populasi dari penelitian ini adalah Bank Umum Syariah di Indonesia yang terdaftar di laporan tahunan Bank Indonesia antara tahun 2009 sampai 2018, dimana tahun 2009 digunakan untuk menentukan data yang menggunakan data tahun sebelumnya (t-1), dan total yang digunakan dalam penelitian ini adalah sebanyak 99 sampel. Pengumpulan data dalam penelitian ini termasuk dalam kategori data sekunder yang diperoleh dari Laporan Keuangan Tahunan Bank yang telah diaudit yang diperoleh dari situs Bank Indonesia (www.bi.go.id). Sedangkan teknik analisis data yang digunakan adalah teknik analisis deskriptik dan regresi linier berganda.

\section{Hasil Penelitian dan Pembahasan}

Perbankan Syariah di Indonesia sudah mulai banyak diminati oleh masyarakat di Indonesia yang mayoritas berpenduduk muslim. Berdasarkan pemilihan sample yang sudah diberikan criteria maka diperoleh beberapa nama Bank yang ditunjukkan pada tabel 4.1, antara lain: PT. Bank Syariah Mandiri, PT. Bank Syariah Muamalat Indonesia, PT. Bank Syariah BNI, PT. Bank Syariah BRI, PT. Bank Syariah Mega Indonesia, PT. Bank Syariah Jabar dan Banten, PT. Bank Panin Syariah, PT. Bank Syariah Bukopin, PT. Bank Victoria Syariah, PT. Bank BCA Syariah, PT. Maybank Indonesia Syariah.
Berdasarkan hasil penelitian yang dilakukan pada 11 Bank Syariah di Indonesia periode 2010 sampai 2019 dengan total data sebanyak 99 data laporan keuangan perbankan, maka diperoleh hasil bahwa beberapa risiko yang ada didalam perusahaan perbankan syariah mampu mempengaruhi pembiayaan Murabahah. Berdasarkan table 4.2 diperoleh hasil bahwa nilai signifikansi dari CKPN sebesar 0,022 lebih kecil dari 0.05 yang berarti hipotesis H1a diterima, NPF sebesar 0,000 lebih kecil dari 0,05 yang berarti hipotesis H2a diterima, KRDI sebesar 0,015 lebih kecil dari 0,05 yang berarti hipotesis $\mathrm{H} 3 \mathrm{a}$ diterima, FDR sebesar 0,039 lebih kecil dari 0,05 yang berarti hipotesis $\mathrm{H} 1 \mathrm{~b}$ diterima, Pembiayaan Bagi Hasil sebesar 0,017 yang berarti hipotesis $\mathrm{H} 2 \mathrm{~b}$ diterima dan BOPO sebesar 0,452 lebih besar dari 0,05 yang berarti hipotesis Hc ditolak. Dari ke enam hipotesis yang dilakukan terdapat 5 (lima) hipotesis yang diterima dan 1 (satu) hipotesis yang ditolak. Dan beberapa hipotesis yang diterima di dukung oleh penelitian terdahulu dan beberapa didukung hanya oleh teori karena peneliti sebelumnya belum ada.

\section{Risiko Kredit mempengaruhi Pembiayaan Murabahah pada Bank Umum Syariah di Indonesia}

Berdasarkan hasil analisis data yang dilakukan diketahui bahwa nilai signifikansi CKPN (Cadangan Kerugian Penurunan Nilai) adalah sebesar 0,022 lebih kecil dari 0,05 yang berarti bahwa hipotesis ke satu diterima yang menyatakan bahwa CKPN berpengaruh terhadap pembiayaan Murabahah, dan diketahu nilai Beta sebesar $-0,565$ yang menandakan bahwa CKPN berpengaruh negatif terhadap pembiayaan Murabahah. Semakin tinggi CKPN maka semakin rendah pembiayaan Murabahah yang diberikan oleh perbankan Syariah. Cadangan kerugian penurunan nilai ini terkait dengan fasilitas kredit yang diberikan dan semakin tinggi CKPN berarti semakin tinggi cakupan nasbah yang tergolong pada kredibilitas peminjaman yang kurang bagus bahkan sampai macet. Sehingga dengan cadangan penurunan nilai ini dapat menurunkan tingkat pemberian kredit perbankan sehingga bank kurang mampu menyalurkan pembiayaan termasuk pembiayaan Murabahah yang lebih dominan 
diminati oleh masyarakat. Pada penelitian sebelumnya belum ada yang menggunakan CKPN sebagai variabel $\mathrm{X}$, sehingga ada kebaruan pada penelitian ini yaitu bahwa CKPN merupakan salah satu bagian dari risiko kredit yang mempu mempengaruhi Pembiayaan Murabahah.

Berdasarkan hasil analisis data yang dilakukan diketahui bahwa nilai signifikansi NPF (Non Performing Financing) adalah sebesar 0,000 lebih kecil dari 0,05 yang berarti bahwa hipotesis ke dua diterima yang menyatakan bahwa NPF berpengaruh terhadap pembiayaan Murabahah, dan diketahu nilai Beta sebesar -0,192 yang menandakan bahwa NPF berpengaruh negatif terhadap pembiayaan Murabahah. Semakin tinggi NPF maka semakin rendah pembiayaan Murabahah yang diberikan oleh perbankan Syariah. Rasio ini menandakan bahwa pembiayaan yang tergolong bermasalah dapat mengakibatkan menurunnya tingkat kredit perbankan syariah, jika tingkat pemberian kredit menurun, maka pembiayaan Murabahah juga akan menurun. Hasil penelitian ini didukung oleh penelitian sebelumnya yaitu oleh wardiantika, Lifstin dkk (2016).

Berdasarkan hasil analisis data yang dilakukan diketahui bahwa nilai signifikansi KRDI (Konsentrasi Risiko Penyaluran Dana Kepada Debitur Inti) adalah sebesar 0,015 lebih kecil dari 0,05 yang berarti bahwa hipotesis ke tiga diterima yang menyatakan bahwa KRDI berpengaruh terhadap pembiayaan Murabahah, dan diketahu nilai Beta sebesar 0,045 yang menandakan bahwa KRDI berpengaruh positif terhadap pembiayaan Murabahah. Semakin tinggi KRDI maka semakin tinggi pembiayaan Murabahah yang diberikan oleh perbankan Syariah. Rasio ini menandakan bahwa semakin tinggi nilainya maka semakin tinggi pemusatan pembiayaan dan pemilihan kepada debitur inti atau disebut dengan Prime Customer sehingga pihak perusahaan perbankan mampu memilih debitur mana yang berkualitas dalam hal ini adalah debitur yang tergolong dalam kolektibilitas 1 (lancar) dan memiliki plafond atau limit pembiayaan yang lebih tinggi, sehingga dengan kehatihatian perusahaan ini maka pemberian pembiayaan juga tergolong bagus dan secara tidak lengsung tingkat pembiayaan Murabahah juga tergolong tinggi. Pada penelitian-penelitian sebelumnya belum ada yang menggunakan rasio tersebut, sehingga menggunakan rasio KRDI ini merupakan unsur kebaruan juga dalam penelitian ini.

\section{Risiko Likuiditas mempengaruhi Pembiayaan Murabahah pada Bank Umum Syariah di Indonesia Bank Umum Syariah di Indonesia}

Berdasarkan hasil analisis data yang dilakukan diketahui bahwa nilai signifikansi FDR (Financing to Deposit Ratio) adalah sebesar 0,039 lebih kecil dari 0,05 yang berarti bahwa hipotesis ke empat diterima yang menyatakan bahwa FDR berpengaruh terhadap pembiayaan Murabahah, dan diketahu nilai Beta sebesar 0,068 yang menandakan bahwa FDR berpengaruh positif terhadap pembiayaan Murabahah. Semakin tinggi FDR maka semakin tinggi pembiayaan Murabahah yang diberikan oleh perbankan Syariah. Rasio ini dibentuk untuk mengetahui sejauh mana bank mampu menyalurkan pembiayaan dari total dana pihak ketiga. Semakin tinggi rasio ini menandakan bahwa dana pihak ketiga sangat mencukupi untuk diseimbangkan dengan penggunaan dana untuk pembiayaan. Sehingaa secara tidak langsung pembiyaan Murabahah akan mengalami peningkatan. Hasil penelitian tersebut didukung oleh penelitian yang dilakukan oleh Huseini, Uus Ahmad (2016).

Berdasarkan hasil analisis data yang dilakukan diketahui bahwa nilai signifikansi Pemb. Bagi Hasil (Pembiayaan Bagi Hasil) adalah sebesar 0,017 lebih kecil dari 0,05 yang berarti bahwa hipotesis ke lima diterima yang menyatakan bahwa Pemb. Bagi Hasil berpengaruh terhadap pembiayaan Murabahah, dan diketahu nilai Beta sebesar 0,047 yang menandakan bahwa Pemb. Bagi Hasil berpengaruh positif terhadap pembiayaan Murabahah. Semakin tinggi Pemb. Bagi Hasil maka semakin tinggi pembiayaan Murabahah yang diberikan oleh perbankan Syariah. Hal ini menandakan bahwa seluruh pembiayaan dengan akad bagi hasil yang menggunakan metode profit and loss sharing maupun Revenue Sharing dapat memenuhi kebutuhan akan pembiayaan 
Murabahah kepada nasabah. Pada penelitianpenelitian sebelumnya belum ada yang menggunakan rasio tersebut, sehingga menggunakan rasio Pemb. Bagi Hasil ini merupakan unsur kebaruan juga dalam penelitian ini.

Risiko Operasional mempengaruhi Pembiayaan Murabahah pada Bank Umum Syariah di Indonesia Bank Umum Syariah di Indonesia

Berdasarkan hasil analisis data yang dilakukan diketahui bahwa nilai signifikansi BOPO (Beban Operasional Pendapatan Operasional) adalah sebesar 0,452 lebih besar dari 0,05 yang berarti bahwa hipotesis ke lima ditolak yang menyatakan bahwa BOPO berpengaruh terhadap pembiayaan Murabahah, dan diketahu nilai Beta sebesar 0,029 . rasio ini dibentuk untuk mengukur tingkat efisiensi bank dalam meminimalkan biaya operaional untuk menghasilkan pendapatan operasional. Dalam penelitian ini BOPO tidak berpengaruh terhadap tinggi rendahnya pembiayaan Murabahah, hal ini terjadi karena tingkat pendapatan operasional di perbankan Syariah tidak mengindikasikan bahwa pendapatan tersbut dapat memberikan peluang yang lebih tinggi terhadapa pemberian pembiayaan Murabahah.

Tabel 4.1 Nama Bank Umum Syariah

\begin{tabular}{|c|l|}
\hline NO & \multicolumn{1}{|c|}{ NAMA BANK } \\
\hline 1 & PT. BANK SYARIAHMANDIRI \\
\hline 2 & PT. BANK SYARIAHMUAMMLAT INDONESIA \\
\hline 3 & PT. BANK SYARIAH BNI \\
\hline 4 & PT. BANK SYARIAH BRI \\
\hline 5 & PT. BANK SYARIAHMEGA INDONESIA \\
\hline 6 & PT. BANK SYARIAHJABAR DAN BANTEN \\
\hline 7 & PT. BANK PANIN YYARIAH \\
\hline 8 & PT. BANK SYARIAH BUKOPIN \\
\hline 9 & PT. BANK VICTORIA SYARIAH \\
\hline 10 & PT. BCA SYARIAH \\
\hline 11 & PT.MAYBANKINDONESIA SYARIAH \\
\hline
\end{tabular}

Sumber : www.idx.co.id, www.bi.go.id (data diolah)
Tabel 4.2 Hasil Analisis

\begin{tabular}{|l|c|l|}
\hline \multicolumn{1}{|c|}{ Variabel } & B & \multicolumn{1}{c|}{ Sign } \\
\hline Constant & 14,211 & \\
\hline CKPN & $-0,565$ & 0,022 \\
\hline NPF & $-0,192$ & 0,000 \\
\hline KRDI & 0,045 & 0,015 \\
\hline FDR & 0,068 & 0,039 \\
\hline PEMB.BAGI HASIL & 0,047 & 0,017 \\
\hline BOPO & $-0,029$ & 0,452 \\
\hline
\end{tabular}

Sumber : SPSS 23 (data diolah)

\begin{tabular}{|ccc|}
\hline $\mathrm{Y}=$ & $14,21-0,565 \mathrm{CKPN}$ & $-0,192 \mathrm{NPF}$ \\
& $0,045 \mathrm{KRDI}+$ & $0,068 \mathrm{FDR}$ \\
& $+0,047 \mathrm{PEMB} . \mathrm{BAGI}$ & HASIL \\
& 0,029BOPO + e & \\
\hline
\end{tabular}

Keterangan:

$\mathrm{Y} \quad=$ Pembiayaan Murabahah

b1 - b6 $=$ Koefisien Regresi

$\mathrm{X} 1=\mathrm{CKPN}$ (Cadangan Kerugian Penurunan Nilai)

$\mathrm{X} 2=\mathrm{NPF}$ (Non Performing Financing)

$\mathrm{X}=\mathrm{KRDI} \quad$ (Konsentrasi Risiko Penyaluran Dana Kepada Debitur Inti

$\mathrm{X} 4=$ FDR (Financing to Deposit Ratio)

$\mathrm{X} 5=$ Pemb. Bagi Hasil (Pembiayaan Bagi Hasil)

$\mathrm{X} 6=\mathrm{BOPO} \quad($ Beban Operasional Pendapatan Operasional)

$\mathrm{a} \quad=$ Konstanta

$\mathrm{e} \quad=$ error

5. Kesimpulan, Keterbatasan dan Implikasi Hasil Penelitian

Kesimpulan yang diperoleh dalam penelitian ini antara lain :

1. Risiko Kredit yang diproksikan oleh rasio CKPN (Cadangan Kerugian Penurunan Nilai), berpengaruh negatif signifikan terhadap pembiayaan Murabahah Bank 
Umum Syariah di Indonesia periode 2009-2018, dimana semakin tinggi nilai CKPN maka semakin rendah pembiayaan Murabahah yang disalurkan, hal ini dikarenakan semakin tinggi CKPN berarti semakin tinggi nasabah yang tergolong pada kredibilitas peminjaman yang kurang bagus bahkan sampai macet. Sehingga dengan cadangan penurunan nilai ini dapat menurunkan tingkat pemberian kredit perbankan sehingga bank kurang mampu menyalurkan pembiayaan Murabahah.

2. Risiko Kredit yang diproksikan oleh rasio NPF (Non Performing Financing), berpengaruh negatif signifikan terhadap pembiayaan Murabahah Bank Umum Syariah di Indonesia periode 2009-2018, rasio ini menandakan bahwa pembiayaan yang tergolong bermasalah dapat mengakibatkan menurunnya tingkat kredit perbankan Syariah, sehingga semakin tinggi NPF maka dapat menurunkan tingkat pembiayaan Murabahah.

3. Risiko Kredit yang diproksikan oleh rasio KRDI (Konsentrasi Risiko Penyaluran Dana Kepada Debitur Inti), berpengaruh positif signifikan terhadap pembiayaan Murabahah Bank Umum Syariah di Indonesia periode 2009-2018. KRDI digunakan untuk mengukur tingkat risiko debitir inti akibat konsentrasi penyluran dana kepada debitur inti. Data debitur inti mengacu pada ketentuan laporan berkala bank Umum Syariah, semakin tinggi KRDI yang dimiliki oleh perbankan Syariah maka semakin tinggi pula tingkat pembiayaan Murabahah yang disalurkan kepada nasabah.

4. Risiko Likuiditas yang diproksikan oleh rasio FDR (Financing Deposit Ratio), berpengaruh positif signifikan terhadap pembiayaan Murabahah Bank Umum Syariah di Indonesia periode 2009-2018, rasio ini digunakan untuk menilai sejauh mana bank mampu menyalurkan kredit dari total dana pihak ketiga, semakin tinggi FDR maka semakin tinggi pula tingkat pembiayaan Murabahah yang disalurkan kepada nasabah.

5. Risiko Kredit yang diproksikan oleh rasio Pembiayaan Bagi Hasil berpengaruh positif signifikan terhadap pembiayaan Murabahah Bank Umum Syariah di Indonesia periode 2009-2018, rasio ini untuk menilai seluruh pembiayaan dengan akad bagi hasil yang menggunakan metode profit and loss sharing maupun Revenue Sharing, semakin tinggi nilai atau hasil dari Pembiayaan Bagi Hasil maka semakin tinggi pula tingkat pembiayaan Murabahah yang disalurkan kepada nasabah.

6. Risiko Kredit yang diproksikan oleh rasio BOPO (Beban Operasional Pendapatan Operasional) tidak berpengaruh terhadap pembiayaan Murabahah Bank Umum Syariah di Indonesia periode 2009-2018. Rasio BOPO digunakan untuk mengukur tingkat efisiensi bank dalam meminimalkan biaya operasional untuk menghasilkan pendapatan operasional, rasio ini.

Keterbatasan dalam penelitian adalah fokus pada Bank Umum Syariah, dan jumlah yang digunakan masih ada 11 Bank Umum Syariah, untuk penelitian selanjutnya dapat menambahkan Unit Usaha Syariah sebagai perbandingan sejauh mana risiko-risiko yang digunakan dalam menentukan pembiayaan Murabahah diantara Bank Umum Syariah dan Unit Usaha Syariah.

Implikasi hasil penelitian untuk perbankan Syariah adalah dapat meminimalisasikan risiko-risiko yang ada diperusahaan agar pembiayaan Murabahah sesuai dengan permintaan nasabah. Dan dapat dijadikan salah satu refrensi dalam penelitian selanjutnya dengan menambahkan beberapa risiko-risiko yang lain yang ada dalam perusahaan perbankan Syariah di Indonesia

\section{Daftar Pustaka}

Ali, H., \& Miftahurrohman, M. (2016). Determinan yang mempengaruhi 
pembiayaan murabahah pada perbankan syariah di Indonesia. Esensi: Jurnal Bisnis dan Manajemen, 6(1), 31-44.

Ghozali, I. (2016). Desain penelitian kuantitatif dan kualitatif untuk akuntansi, bisnis, dan ilmu sosial lainnya. Semarang: Yoga Pratama.

Hasibuan, M. S. (2006). Dasar-dasar perbankan. Jakarta: Bumi Aksara.

Husaeni, U. A. (2016). The Variables that Affect Murābaḥa Financing in Islamic Commercial Banks. International Journal of Nusantara Islam, 4(2), 1-16.

Imam, G. (2013). Aplikasi Analisis Multivariate dengan Program IBM SPSS 21 Update PLS Regresi. Semarang. Badan Penerbit Universitas Diponegoro. ISBN, 979(015.1).

Prastanto, P. (2013). Faktor Yang Mempengaruhi Pembiayaan Murabahah Pada Bank Umum Syariah Di Indonesia. Accounting Analysis Journal, 2(1).

PSAK IAI. 2017.Pernyataan Standard Akuntansi Keuangan Nomor. 101 tentang Penyajian Laporan Keuangan Syariah. Jakarta:IAI.
PSAK IAI. 2017.Pernyataan Standard Akuntansi Keuangabn Nomor. 102 tentang Akuntansi Murabahab. Jakarta:IAI.

Surat Edaran No. 3/30 DPNP dated 14 December 2001 Tentang Pedoman Perhitungan Rasio Keuangan.

Undang-Undang No.10/1998 tentang Perubahan atas Undang-Undang Nomor Tahun 1992 tentang perbankan.

Wardiantika, L. (2015). Pengaruh DPK, CAR, NPF, dan SWBI terhadap pembiayaan Murabahah pada Bank Umum Syariah tahun 2008-2012. Jurnal Ilmu Manajemen (JIM), 2(4).

www.bi.go.id.

www.OJK.go.id (Roadmap Perkembangan Keuangan Syariah Di Indonesia Tahun 2017 - 2019), diakses per 20 April 2019.

Yaya, R., Martawireja, A. E., \& Abdurahim, A. (2009). Akuntansi Perbankan Syariah: Teori dan Praktik Kontemporer. Penerbit salemba empat.

Yusuf, M. B. M., \& Sabri, B. (2014). Islamic Credit Risk Management in Murabahah Financing-The Study of Islamic Banking in Malaysia. Australian Journal of Basic and Applied Sciences, 8(6), 318-323. 